\title{
Brazil and USA Cross-Cultural Study of Sport as Motivational Factor in Education
}

\author{
Antonio Jose Müller ${ }^{1}$ \\ ${ }^{1}$ Education and Physical Education Departments, Universidade Regional de Blumenau, Brazil \\ Correspondence: Antonio Jose Müller, Education and Physical Education Departments, Universidade Regional \\ de Blumenau, Brazil. E-mail: antoniomuller2@hotmail.com
}

$\begin{array}{lc}\text { Received: September 15, } 2014 & \text { Accepted: October 21, } 2014 \quad \text { Online Published: November 26, } 2014 \\ \text { doi:10.5539/ies.v7n12p76 } & \text { URL: http://dx.doi.org/10.5539/ies.v7n12p76 }\end{array}$

\begin{abstract}
In every country, school is considered an essential factor in the development of children, citizens, and the country as a whole. In developing countries such as Brazil, however, the number of school dropouts is very high. In developed countries such as the United States, there is an urgent need for pedagogical improvements. Participants were thirty-four high school students from four different schools, divided into low-income and high-income groups in both countries. The intention of this study is to demonstrate how sport can develop its role to contribute to the promotion of academic motivation under Freirean perspectives.
\end{abstract}

Keywords: sport in schools, sport and academic motivation, cross-cultural study

\section{Introduction}

Sport is one of the most important sociocultural phenomena in the world. Its social significance when connected with education, participation, and performance can be interpreted as a distinctive democratic opportunity for humanity as a whole. Furthermore, sport can exert a foundation for socialization of the minorities or underprivileged classes. Historically, however, sport also reflects socioeconomic and ethnic differences, assuming its magnitude as a type of imposition and repetition of the status quo. For example, during the Roman Empire, gladiators were used to enforce the law by killing prisoners of war, criminals, or Christians. This setting of human beings to kill one another in public for entertainment was a dreadful savagery to maintain the order and keep social class divisions (Grant, 1967). The adoption of a realistic attitude about this aspect of gladiatorial brutality is all the more necessary in our own twenty-first century where black athletes, mostly from low social classes, play sports to entertain those people who have money to buy expensive tickets or pay-per-view transmission.

In Brazil, the number of school dropout is very high. Many issues contribute to this reality, from malnourished students and the persistence of social stratification, to inadequate connections between the school and the students. In developed countries like the United States, there is an urgent need for reform in curriculum and pedagogical issues. With the system of accountability based on test results, as well as the lack of sufficient funds, means that there is a decline in the importance of extracurricular activities like sports and music. Thus, due to the expansion of more time and concern on the test results, rather than the students appreciate.

In Texas, a policy was developed, "No pass, no play", where academics must become first and then sport. Youth receiving additional physical activity tend to show improved attributes such as increased brain function and nourishment, higher energy/concentration levels, changes in body build affecting self-esteem, increased self-esteem and better behavior which may all support cognitive learning (Scheuer \& Mitchell, 2003). However, there is little research which explores the precise relationship between sporting activity and educational performance, and the evidence about the relationship between physical activity, cognitive benefits and academic performance is somewhat inconclusive.

Most studies agree that participation in sport under deliberate practice, or behavioral training, of fair play and positive social behavior can stimulate students academically. Yet, such outcomes do not happen automatically (Hastie \& Sharpe, 1999). Another point is that the popularity of sporting activities for many young people has led others to argue for its consideration by schools seeking to address the problem of truancy (Coalter, Allison, \& Taylor, 2000). Some studies report generally positive outcomes in terms of pupil attendance following the 
introduction of sports-based schemes (Long et al., 2002), and an increase in the availability of sporting activities would make the school experience a more attractive option (Coalter, Allison, \& Taylor, 2000).

Students' interest in sport could be better connected to improve education since the principle of sport-education is eminently social when sport is involved as an educational expression with an essentially educative function. However, the exaggerated importance of sports in schools and universities changed this conception, and sport-education is no longer respecting the purity and full benefits of their educational function.

The cause of school's lack of interest includes the absence of skills in social competency, problem solving, and direction. Sport could change this aspect through the development of a sport curriculum focusing on positive social behaviors, improving skill-based performance of students, and helping them to be better self-and peer-monitors of positive social practices within sport itself (Hastie \& Sarpe, 1999). Interest in school can increase by sport participation, and a sport motivational approach can help understand the views of adolescents, which may influence their motivation to increase interest in academics (Allen, 2003). Through Physical Education (PE) class children can discover new experiences and develop solutions according to their own understanding. The repetition of these real and significant experiences may improve their motivation and consciousness. Under this perspective, physical activities with the purpose to develop positive social integration might result in the capacity to increase students' interest in schools.

This study is an investigation of the influences of sport in schools in that it challenges understanding how sport is identified in its academic motivation in Brazil and in the United States. This study offers an overview for sport connected to education under a cross-cultural perspective with the objective of understanding the characteristics of each culture. The purpose of this study is to examine and analyze, using qualitative methods and Freirean theories, the relationship between sports and its cultural, and educational influences in Brazilian and U.S. societies. In addition, this research demonstrates how sport can develop its role to contribute to the promotion of academic motivation.

\section{Method}

This is qualitative research, which uses ethnography, meaning that the qualitative analysis focuses on the process and product of describing and interpreting cultural behavior (Schwandt, 2007), uses also interviews as qualitative data strategies to collect information and critical hermeneutics as a methodological approach to analyze the information. The ideological framework used in this research is based on Freirean perspective, which determines the focus of inquiry. This study is held to be cross-cultural-or cross-national-and comparative; therefore, I may call it comparative ethnography. The idea is to examine particular issues in two countries with the express intention of comparing their manifestations in different sociocultural settings, such as schools, customs, traditions, lifestyles, using the same research instruments either to carry out secondary analysis of national characteristics and data or to conduct new experimental work.

In each country, I chose two schools in the same city (El Paso, TX, USA and Blumenau, SC, Brazil). I decided to interview students from two different schools in each country, according to students' SES (Socio-Economic Status). In El Paso I chose Irvin High School (78.5\% economically disadvantaged student body) and Franklin High School (22.3\% economically disadvantaged student body). In Blumenau, I chose Colégio Estadual Luiz Delfino (public school composed predominantly of low-income students) and Colégio Bom Jesus (private school predominantly composed of high income students). Two groups of students from the same school were surveyed. One was a group of student/athletes and another, was a group of regular students. The research lasted for approximately three months in the U.S. and one month in Brazil.

Interview results are composed by specific group of four participants each, and results reported from two groups from the same school, one group with students and another with student/athletes, in the same city. Therefore, I have eight divided groups, from low and high SES and regular students or student/athletes. The participants consisted of thirty-four male and female high school students (18 in El Paso, TX, USA and 16 in Blumenau, SC, Brazil). They ranged in age from 15 to 17 years. The participants were divided into low-income (or economically disadvantaged) and high-income groups. So that the participants would be roughly representative of students in this age range, students were not specifically selected for their involvement in a specific sport or sports. High school students were chosen because they were at the time in their life where sport and academic should be used for transition for college or profession.

This research used the same qualitative information approach in both countries; therefore, this study enabled the possibility of comparisons at the same level. It showed the cultural and educational differences between them and the effects of different political and economic circumstances. I conducted semi-structured interviews lasting 30-45 minutes. These questions focused on their descriptions of the school; characteristics of student and 
student/athletes; their beliefs and expectations; and sport that contributes or not to learning opportunities. For anonymity, the names of the interviewees do not correspond to the real name. For references on the interviews transcriptions below: PS meaning Public School (Brazil) and LI meaning Low Income (U.S.)

\section{Results}

\subsection{Similarities and Differences between Students'Beliefs Concerning Sport Benefits and Drawbacks}

\subsubsection{Emerged Themes from Brazilians}

In Brazil, I identified emerging themes throughout students' interviews and my observations. These sub-themes are important in explaining the fundamental theme because they provide an explanation of why sport is a factor in motivating students in school. In Brazil, through the interviews in relation to sport and academic motivation, the following sub-themes emerged:

\subsubsection{School Is Boring}

In Brazil, most participants mentioned that the school is not an exciting place to be. Students from low SES complain more about school. Their great concern was connected with the lack of options making school more attractive. Robson (PS) compared the situation of his public school with the better situation in private schools. He said, "In private schools you have computer class, the next day we have music class sure in private school they have it. Here, the classroom is super crowded, there is a lack of space, and if you seat in the back, you never listen to what the teacher is saying." Student/athletes said that school is boring for regular students. Again, athletes mentioned their routine is better, and it seems they have more enthusiasm and better, behavior in school in comparison with non-athletes. Priscilla (PS), 15 years old, basketball player, said, "Wake-up in the morning, go to school, go back home, sleep all day, do not expend energy, don't use time for nothing, and back to school, boring routine".

Through the interviews I perceived that students in sports believe that education is important, and they have more respect for teachers. Perhaps, because they feel the harmony between authority and freedom, discipline necessarily implies respect of the one for the other (Freire, 1998a), as they learn in sport. As Isabela assumed, "I started playing and now I feel better in school. But school is not as much fun as sport. I do not know how, but in sport, I am learning to change for the better. I don't know how, but my grades are better now after I started playing." She believed her improvements in academics were because of sport, and she assumed school was less boring with sport.

\subsubsection{Teachers Are Not Prepared}

Students from the low SES have less enthusiasm and interest in school. Student/athletes in Brazil demonstrate more passion in their comments. In Brazil, regular students more than athletes, and from low SES rather than high SES, complained about teachers' preparation and enthusiasm. Felipe (PS), a 16 year old, white basketball player, said, "Teachers are not motivated, and they are not prepared for class. They come with the book, and this is for today and that is all." He completed "I think they are not motivated because they received a low salary. Then they come to teach, and direct their anger toward students all morning". According to Freire (1998b) many people enter into the educational field because they lack other opportunities, much less as something to pass the time while waiting for marriage. In Brazil, most teachers receive extremely low salaries, this is a strong demotivating factor, and the teaching career seduced no one. As Felipe said, "They come stressed to school" because by receiving a low salary, teachers consider themselves less important and dispensable. I explored interviews by asking what could be better used in school and sport to improve education. Daniele, a very happy 16 years old plays handball for the city team. She said, "I think sport and education must "walk" together stimulating each other." Then I asked how can we do that, and she said, "I think it would start with the teacher. We need teachers stimulating students, more extracurricular activities, and an increase in number of hours in school."

Sports are a thematic topic included in the students' context. Isabela mentioned, "You have many different situations in sport, and you put that situation, sometimes, into practical situations in your life." By using Freire's method, sports would be included in the cultural generator theme, as a factor to stimulate learning. The interdisciplinary technique aims at relating sports to other subjects. To understand how theory can be related to practice, or how sport can be used in regular classes, I asked participants, and Robson (PS) said, "Why don't teachers explore the topic better?" I asked, "Like what?" He said, "In physics for example, we can through the ball and see prove the theory with the ball, speed, high, and distance. Pure physics" I thought this was a very good idea. By using sports in regular classes many things could be more connected with really interesting aspects of learning. His idea can be used to diminish the gap between theory and practice. 
The better on this process, theory is identified with practice; the greater is the gain in intelligence and the greater the possibility of stimulating epistemological curiosity and creativity. This pedagogy is the pedagogy of freedom as Freire (1998a) points out that a democratic teaching practice ought to reveal in its relationship the freedom of students in a sense of its own self-confidence. Self-confidence, however, must be present in teachers and be grounded in professional competence, since "teachers are not motivated." I asked why good practices are not happening in classes, and Felipe (PS) answered, "Some students are not motivated teachers also are not to create attractive classes." Students are not motivated because of teachers. This is not pedagogy of freedom because teachers are immersed in their small world and this includes their students. They are unable to see it, and with the association of theory and practice, they both emerged and were thus able to see it, as they never had before (Freire, 1998b). In both countries, PE is the way that can stimulate regular students to be motivated and included. In reality, PE is still recognized as a component of curriculum in a position of inferiority and marginality in the schools' hierarchy. Teachers are mainly responsible for this situation. The situation contributes to the perpetuation of the status quo.

\subsubsection{Student/Athletes Are More Motivated}

Many participants agreed that athletes are more motivated than regular students are. I asked how they felt during the sport practice and games and asked for some examples. Priscilla believed, "I think they are freer, more spontaneous to live. People that have more desire to do the things do not fall in a routine. People that don't play sports are in a routine and forgetting everything else". This comment expressed not only the motivation, but also the autonomy that athletes have. They have fun in their lives because of sport. They have autonomy and assume responsibility for their actions because "they are freer and more spontaneous to live." Maybe athletes are taking the risk to express their opinions, as they feel more encouraged to do so. Priscilla said, "I think sport is nice. I did sports and a person feels more confident, losing the shame, feeling more comfortable to speak with everybody. You are more popular in school." She reflected her experiences and said her high self-esteem was compatible with the learning and practice of becoming a "subject" (Freire, 1998a).

\subsubsection{Sport Helping Education}

The theory that sport can help education is important but not very clear. Sport-education is used on a regular basis in schools in different countries with the objective to provide an integral and complete development through physical-cognitive connections. During the interviews, many points explained the connections and benefits of sport as an academic motivator. Marco said that sport is important because it helps concentration in class. He said, "Concentration helps us to think better in sport or in school where we are concentrated in something."

Decision-making is common in sports and can be an important tool to improve education. Especially in team sports, students or athletes need to make decisions almost every second during the practice or game. This decision-making process is a critical part of the game which coaches call tactical intelligence. Isabela said, "In sport we need concentration to see the game situation. In sport we develop our decision to answer the questions and the capacity to make decisions faster". Her comment is very close to what I understood, as a decision making process that is very helpful in academics. Children are excited to play, and this can promote a perfect environment to produce knowledge. Another point is that sport helps to improve concentration, and this can be very important in the learning process. Isabela said, "If you can concentrate in the game or situations, you can come to classes and pay attention to the teacher, concentrate, during the test and you feel more relaxed." With concentration students can think correctly. As Freire (1998a) explores "To think correctly implies the existence of subjects whose thinking is mediated by objects that provoke and modify the thinking subject" (p. 42). Freire emphasizes the importance of intellectual work, the production of the theory of education as a practice of freedom.

I was very impressed with the comments, and I tried to explore further and asked their opinions about sport in school or sport and academics. Priscilla, a basketball player, had a good point. She said, "You are doing sport because you like it and you have to think during sport. It helps you to have better reasoning." I asked her to prove that it was true. She started laughing and said, "My grades are better now after I started playing." The connection between sport and academics is easy to understand. Students feel good in sport. They feel motivated doing sport and this motivation is transferred to other activities in their routine, such as school. In addition, they need to think during sport, and they are making decisions, therefore, this is a process of critical thinking that can be transferred to regular classes. Tiago, stated, "For example, if I have the basketball in my hands, I need to pass, but I need to think the opposite player can "cut" the pass chooses the best way. I need a fast decision." This is another example of critical thinking in the real world. Freire (1998a) said that real knowledge moves us to active 
mobility with creativity and adventure. Because sport is a kind of passion, people are capable of critical learning, and learning in sport never leads to passive mobility.

\subsubsection{Emerged Themes from Americans}

In the U.S., I identified emerging themes throughout students' interviews and my observations. The fundamental theme is to understand sport as an academic motivator through minor themes. Some themes are the same as those I found in Brazil, but some different themes emerged. In the United States, the following sub-themes emerged:

\subsubsection{School Is Boring}

The same comment about school appears in Brazil and is repeated in the U.S. One factor causing school to be boring is that of the teaching process is related to the accountability system. The idea is to improve education and establish an accountability system based on test results. Accountability, however, is not synonymous to testing, and testing is not the answer to an educational crisis (Huffington, 2001; Rossatto, 2004). Nicholas said, "It is impossible to make 100 in every class as the teachers expect, if you don't get a good grade, you feel more stress then you start to dislike school." In reality, schools are failing many students, especially minorities, by placing both curricular and budgetary emphasis on standardized tests which can keep poor people and people of color away from a wide and meaningful curriculum that can assist them to move up on the social class scale (McNeil \& Valenzuela, 1998).

During the interviews, I started talking about how school could be a better place, and Nicholas, a 17 year old, student from Franklin, expressed his frustration that there too many rules. He said, "School sucks, it is related to a prison. There were too many things you can't do and not enough things you can do". Represented essentially by teachers, schools are a place with students confusing authority and authoritarianism, freedom and license. One can really perceive the absurdity of authoritarianism that all school space belongs to the educational authorities and teachers (Freire, 1998b). School space does not belong to students, and they were in the space but not with the space. Schools must be democratic places to prepare critical-thinking citizens. No one lives democracy fully if he/she is interrupted in his/her right to speak, or if he/she is not engaged, in the fight to defend this right, which is the right to act (Freire, 1998b) and play.

\subsubsection{Teachers Are Not Prepared}

The same as in Brazil, students from the low social class have less enthusiasm and interest in school. Moreover, student/athletes demonstrate more passion in their comments. I asked what the problem in schools was, and many comments were about teacher motivation or preparation. Nicholas expressed his opinion, "I had learned the same thing the entire semester. I feel like I just wasted nine months of my life. Teachers do not care. Teachers teach for money. They do not teach the students, and they are really lazy.

\subsubsection{Student/Athletes Are More Motivated}

Student/athletes showed their excitement about sport, and I asked if they had that excitement in school. The level of expectation in Franklin is completely different from Irvin besides of common problems of lack interest in school. Moreover, student/athletes demonstrate more respect, and some are happy with the level of instruction they are receiving. Ryan, an athlete, said, "School is boring many times, but we have so many friends, and in one way or another you associate with your group, and school is a lot a fun. It is where your friends are, especially here at Franklin. Our teachers are cool, a lot are very energetic, they teach class in different ways, and every year there is something new." It was amazing how students from the same school and classes have such different opinions about school. These differences appear between students in or out of sport. I asked student/athletes if they have the same passion to go to school as they go to sport, and Ryan answered, "I really don't, because it is different when you are playing sport and when you are going to class, doing homework, essays, and tests. It is totally different because when you do sports it's much more fun than sitting down". He exposed many problems in education. If sport is more fun, it is because classes are not. If school is boring, it is because sport is not. If teachers are unprepared and unmotivated, it is because coaches are not.

In sport, athletes are improving their skills and becoming socialized. Maybe these two important objectives in sport can promote confidence. Jordan and many youths in sport are experiencing themselves in secure adolescence, feeling themselves to be capable and secure about their own creative possibilities, and living in peace with the world (Freire, 1998a). Many athletes expressed their excitement about sport and transferred their satisfaction to school. Regular students complained more about school and teachers. Perhaps they do not have in school what they see as important in their lives. It is because of our traditional curriculum, disconnected from life, centered on words emptied of the reality they are meant to represent, lacking in concrete activity that could never develop a critical consciousness (Freire, 1973) as Jordan said, "Sport is a part of my life. I cannot even 
imagine it without it." As the same to say, I love music, if I have music in school, therefore, school it will be a better place to go.

\subsubsection{Sport Helping Education}

Many students agreed that school is a better place because they have sport. A better place to be is a better place to learn. Hiliana (LI), a 16 years old Mexican-American young woman, from Irvin HS said, "School is boring, and sport makes a difference having something else to do. It is one good reason to come to school. Sport pushes you as a motivator." Ben said he preferred PE because "It is kind a fun. Definitely, I look forward to my sports class more than like my English class or something." I asked what school would be like without sport, and Sergio said, "School would be no fun, and a little boring." Desmond (LI), an African-American basketball player from a low SES, expressed the idea that "School is good because of sport." Then I asked how school could be more fun because of sport, and Sergio (LI) said, "In sport you represent your school in a game, which is good. For me, I want to play college ball and get my education. You can't play college ball if you don't get an education. That's why I need sports".

The connection between sport and education is stronger in the U.S. because public schools offer the opportunity to play sports and get an education in greater numbers than in Brazil. The "no pass, no play" policy was the main reason they believe sport helped education. Valerie summarized, "Sport it's a way to motivate students to pass in class because if they don't pass, they don't let you play. Sport made school more important because you need to pass to play. I think it is fair". The "no pass, no play" policy is considered a good thing for all students. They recognized that policy as important. Javier commented, "Sports help you to keep your grades up. We have to pass to keep playing." They agreed that some students are good in sport but cannot participate in sports because of low grades. Ryan mentioned something important. "Sport is good to achieve academic goals and become a better student. I am not sure about everybody else, but academics is something we have to stress because of the "no pass, no play" law, we have to study more".

Jordan made a point and summarized the theory of sport as a motivator in school. She said, "I think people having success on the court are the same ones having success in the classroom because they have a drive to succeed no matter what it is, and even those people that don't enjoy school as much as the rest of us, have a new motivation". Because of this reality, students are involved in the critical perception of the concrete not in the abstract (Freire, 1970). They are recognizing their importance and reflecting their opportunities in various dimensions.

\section{Discussions}

The results obtained throughout this study and the researcher's insights acquired throughout the implementation and interpretation of findings led to recommendations as follows:

\subsection{Promoting Inclusion in PE and Sport}

In relation to social inclusion in education, the objective of sport in school, through PE classes, must demonstrate that it is used as socially inclusive in providing sport opportunities as well as the ability to structure an inclusive curriculum that meets the needs of all pupils. To reach this status, it is necessary for more funding and for making PE and school sports a greater priority within government policy. By effective implementation of sport classes based on critical understanding of sport importance and issues inspired by Freire's theories demand strong commitment from the stakeholders in both countries.

\subsection{Making Sport More Important in Schools}

Although sport is well appreciated by young people, few schools in Brazil and in the U.S. give sports the importance they should have. Physical education, not team sports, is part of the Brazilian curriculum but is not deeply explored as sport initiation. One of the reasons is the lack of resources such as coaches' payment, facilities and equipment. These sport classes could provide existing students with better sports development and improvement. Sport classes could also expand educational opportunities by recruiting the children who currently do not attend school. Schools in the U.S. offer physical education classes aimed at physical formation and health. They could increase participation by creating sport classes divided in level of skills of students, without considering age or gender especially for at-risk students because statistics show that at-risk children in the poorest neighborhoods. Currently, many of these potential students are not engaged in any form of education. Sports should be the recruitment tool that entices students to enroll and stay in school with the inclusion of sport classes in public schools in Brazil and with the empowerment of sport as an educational tool in the U.S. 


\subsection{Sport Classes in Various Levels in the U.S.}

In the U.S., introduce sport and physical activities classes with different objectives for people who like sport and do not like sports. Explain the benefits of physical activity and socialization. Many people are not encouraged to start in sport because they believe they lack talent or they have no interest in the level of competition that school teams provide today. Sport classes should be divided into the level of skills of students, without considering age or gender.

\subsection{Sport More Connected with School in Brazil}

In Brazil, sport competition is connected with clubs. Many youth are dropping out of school to focus on sport. The idea is that any young athlete must be in enrolled in school and passing in his/her classes to be able to compete. Therefore, sport leagues that are organizing competition must introduce the rule that to be able to play, you must be enrolled in school and passing in your classes.

\subsection{Scholarships for Brazilian Athletes}

Brazil could start applying the scholarship system for talented student/athletes so they can get a higher education without necessarily dropping sport practice. These new opportunities could increase students' interest in obtaining an advanced degree. The integration of sports and education can promote equality, especially targeting underprivileged students.

This study demonstrated and compared education and sport in Brazil and in the United States. Through the comparison, many positive issues were covered. However, many negative issues were also covered. Based in this research, students in general have more enthusiasm in sport than education. My recommendation is that teachers and coaches could use this valuable link to improve the interest of students in their educational performance by showing the importance of academics at the same level of significance and interest as that of sport.

In Brazil and in the United States some students have left school or are unmotivated with the educational process for many different reasons, such as economic problems, social problems, or problems related to the curriculum. Freire (1998, p. 6) said, "In reality, we do not have children who drop out of school for no reason at all, but they just decide not to stay. What we do have are conditions in schools that either prevent them from coming to school or prevent them from staying in school". Problems related to lack of interest, dropouts, discipline, and low level of literacy can diminish by students' desire to stay in school. Sport is a useful tool to provide students' interest in school by encouraging the participation to be socialized and academically motivated.

Brazil needs to understand the importance of sport in schools and promote some type of policy that children improve academics throughout their participation in extra-curricular activities. Brazil should encourage sport in school just as the U.S. does. The benefit of sports is academic motivation, more than the excessive importance of competition as in the U.S. Sport in higher education is also very important and should be used in Brazil. Policies such as, "no pass no play" is making many important changes to promote motivation in American society. The same kind of idea could be used in Brazil, with the adaptation of cultural, political, and economic realities.

This study compares beliefs from two countries and beliefs from participants from low and high incomes. Therefore, even in the same country, one context can be totally different from low and high income. At the same, one context can be similar with people in the same social status in different countries. Clearly, in this research, however, people from a different social status almost never have the same beliefs. The importance of sport in one's life can be very different according to his/her history and social situation.

\section{References}

Allen, J. B. (2003). Social motivation in youth sport. Journal of Sport \& Exercise Psychology (Dec 2003, Vol. 25, Issue 4).

Coalter, F., Allison, M., \& Taylor, J. (2000). The role of sport in regenerating deprived areas. University of Edinburgh, UK. Retrieved from http://www.sportdevelopment.org.uk/rsrdua-00.pdf

Freire, P. (1970). Pedagogia do oprimido. São Paulo: Paz e Terra.

Freire, P. (1973). Education for critical consciousness. New York: Continuum.

Freire, P. (1994). Pedagogia da esperança. Rio de Janeiro: Paz e Terra Press.

Freire, P. (1998a). Pedagogy of freedom. Ethics, democracy and civic courage. Lahman: Rowman \& Little field Publishers, Inc.

Freire, P. (1998b). Teachers as cultural workers. Letters to those who dare teach. Boulder, CO: Westview. 
Grant, M. (1967). Gladiators. New York: Barnes and Nobles Books.

Hastie, P., \& Sharpe, T. (1999). Effects of sport education curriculum on the positive social behavior of a-risk rural adolescent boys. Journal of Education for Students Placed at Risk, 4(4).

Long, J., Welsh, M., Braham, P., Butterfield, J., Hylton, K., \& Lloyd, E. (2002). Count Me In: The dimensions of social inclusion through culture and sport. London, UK: DCMS.

Mandell, R. D. (1984). Sport a cultural history. New York, NY, USA: Columbia University Press.

Mcneil, L., \& Valenzuela, A. (1998). The harmful impact of accountability rethoric (pp. 1-14). The Civil Right Project Harvard University.

Rossatto, C. (2004). Social justice in times of McCarthyism renaissance. In J. O’Donnell, M. Pruyn, \& R. Chávez (Eds.), Social justice in these times. Greenwich, CT, USA: Information Publishing.

Scheuer, L., \& Mitchell, D. (2003). Does physical activity influence academic performance? Retrieved from $\mathrm{http}: / /$ www.sports-media.org/sportapolisnewsletter19.htm

Schwandt, T. A. (2007). Dictionary of qualitative inquiry. Thousand Oaks, CA, USA: Sage Publications.

\section{Copyrights}

Copyright for this article is retained by the author(s), with first publication rights granted to the journal.

This is an open-access article distributed under the terms and conditions of the Creative Commons Attribution license (http://creativecommons.org/licenses/by/3.0/). 